\title{
Contextualizing privilege and disadvantage: Lessons from women expatriates in the Middle East
}

Organization

$1-19$

(C) The Author(s) 2018

Article reuse guidelines: sagepub.com/journals-permissions DOI: I0.1 I77/|3505084|88|2580 journals.sagepub.com/home/org

@SAGE

\section{Jenny K. Rodriguez \\ The University of Manchester, UK}

\section{Maranda Ridgway}

Nottingham Trent University, UK

\begin{abstract}
This article explores how the simultaneity of privilege and disadvantage shapes the experiences of women expatriates in the Middle East. The article problematizes the simultaneity of being an elite group (e.g. expatriates) and a disadvantaged group (e.g. women) within the context of Gulf Cooperation Council countries. Drawing on the literature about women and work expatriation, the article analyses the narratives of women expatriates to highlight the complexity and multidimensionality of their experiences, positioning the discussion within the framework of gendered institutions. The article concludes that privilege and disadvantage are inseparable to the way the experiences of women expatriates unfold in the Middle East, and that institutional settings articulate this inseparability in order to regulate and help to maintain the gender social order. The article contributes a nuanced understanding of the experiences of women expatriates, challenging dominant views that present this group as generally privileged by virtue of their skilled and mobile status.
\end{abstract}

\section{Keywords}

Disadvantage, gendered institutions, Middle East, privilege, women expatriates

\section{Introduction}

The lives and work experiences of expatriates continue to garner academic attention given the rapid changes in the nature and structure of work in global labour markets, as well as the multilayered, multifaceted features of international workplaces (Al Ariss et al., 2012). As individuals living and 
working outside of their home countries, expatriates have been described in the literature as mobile, elite professionals and their experiences framed in relation to a privileged positioning in host settings (Beaverstock, 2002; Farrer, 2010; Van Bochove and Engbersen, 2015). This is primarily linked to assumptions about what drives organizations to offer them opportunities to undertake assignments abroad as company-assigned expatriates, or their abilities to secure these opportunities abroad independently as self-initiated expatriates. However, regardless of whether expatriates are company assigned or self-initiated, the fundamental differences seem to emerge in relation to gender (Caligiuri and Tung, 1999; Shortland, 2009, 2014). In particular, socio-cultural and political realities present challenges to women expatriates, especially in contexts where gendered division of labour restricts women's participation in the labour market. For instance, the literature about the Middle East has highlighted the historical centrality of patriarchal regimes in defining societal structures, and how patriarchal relationality serves as an organizing principle of social and work relationships (Al-Waqfi and Al-Faki, 2015; Joseph and Slyomovics, 2011).

Expatriates provide a good analytical angle to explore how the narratives of the single global village interact with the national realities of particular regions, such as the Middle East. This region is said to resist the homogenizing forces of globalization, and sees them as a threat to national culture and identity (Fox et al., 2006). The tension between Western and Arab values within the Arab world has been problematized mobilizing the idea of a 'Arab neopatriarchy' (Sharabi, 1992), used to refer to a specific form of patriarchy that results from the contact of the Arab world with European modernity in the imperialist age, which shapes the current social order in the region. This Arab neo-patriarchy could be seen in the way advances to women's equality have materialized, for instance, while women in the region can now engage in work and social life outside the home, they can only do so within particular societal arrangements, such as women-only spaces and work can only be undertaken with the permission of a male family figure (e.g. fathers, uncles or brothers). Ultimately, institutional and cultural barriers are embedded in work systems in ways that affect women in terms of employment rights, development and progression at work (Metcalfe, 2008; Metcalfe et al., 2009).

The previous tensions raise important questions about how the life and work experiences of women expatriates unfold in work settings in the Middle East. The literature about expatriates has largely adopted a gender-neutral approach (Hartl, 2004), oversimplifying the experiences of women expatriates and overlooking the impact their status as women may have in these contexts. While as expatriates these women would not experience societal arrangements in a similar manner as local women in the Middle East (Stalker and Mavin, 2011), they still face diverse challenges resulting from being foreign women working within neo-patriarchal structures. With that in mind, the starting point of this article is that women expatriates are positioned by institutions at the intersection where privilege, from being part of a mobile elite, meets disadvantage, from being women, in male-dominated neo-patriarchal settings. We use the notion of institutions to refer to 'humanly devised constraints that structure political, economic, and social interaction' (North, 1991: 97). While some research on expatriation has alluded to the role of different institutions (e.g. customs, traditions, laws and regulation), the way their resulting dynamics come together to shape women expatriates' experiences remains largely under-researched. In this article, we explore this by focusing on the following question: How do privilege and disadvantage shape the work and life experiences of women expatriates in the Middle East?

In order to explore this question, we problematize the simultaneity of being an elite group (e.g. expatriates) and a disadvantaged group (e.g. women) within the context of Gulf Cooperation Council (GCC) countries, namely Bahrain, Kuwait, Oman, Qatar, Saudi Arabia and the United Arab Emirates. We draw on the literature about women and work expatriation to highlight the complexity and multidimensionality of the experiences of women expatriates, positioning the 
discussion within the framework of gendered institutions (Acker, 1990, 1992). In doing so, we contribute a nuanced exploration of the experiences of women expatriates that moves away from a positioning that focuses on success and/or failures, instead looking to gain insight into the dynamics that shape their experiences amid conflicting positions.

The article is organized into four sections. After this introduction, the first section discusses women and expatriate work in the Middle East, arguing that a more nuanced understanding of their experiences requires that we look to the role of institutions in sustaining gendered structures that support the simultaneous existence of privilege and disadvantage. This discussion shows the unresolved tensions in the extant literature about expatriates, which considers this group as an elite, hence obscuring the challenges they face in host settings. The second section unpacks the intersectionality of privilege and disadvantage, setting out the theoretical underpinning of the article. In this section, we highlight the fluidity of privilege and disadvantage that helped us to interrogate the experiences of women expatriates. The remaining sections explain the methodology, and discuss and analyse findings. The findings are organized around the themes of privilege and disadvantage, where we identify and discuss instances that provided evidence of their simultaneity in the life and work experiences of the women expatriates. The last section concludes and identifies directions for future work.

\section{Expatriate workers in the GCC: the role of gendered institutions}

The GCC is considered the world's region most reliant on expatriate workers (Haak-Saheem and Brewster, 2017; Tahir and Ertek, 2018). Expatriates represent $69.4 \%, 89.9 \%$ and $88.5 \%$ of the population for Kuwait, Qatar and the United Arab Emirates, respectively (Gulf Labour Markets and Migration, 2017). Despite an increase in the labour market participation of women in the Middle East, in what has been considered a sign of societal modernization of the region as a whole (Metcalfe, 2007; Stockemer and Sundström, 2016), women continue to be perceived as inferior to men (UN Women, 2017). The Islamic principle of men and women being equal but holding different social and economic roles (Metcalfe et al., 2009) does not automatically translate into women having legitimate spaces in the labour market.

While women form a significant part of the global workforce, they are largely under-represented in many expatriate work environments (Hutchings et al., 2013; Hutchings and Michailova, 2017; Varma and Russell, 2016). Gender stereotypes and perceptions about women's choices and expectations have been linked to this under-representation, for example, that women are less motivated to expatriate than men, that they are not provided the same organizational support as their male counterparts and that they struggle to adjust to host environments (Adler, 1984; Altman and Shortland, 2008; Andresen et al., 2015; Caligiuri and Lazarova, 2002; Shortland, 2009).

However, recent work (e.g. Altman and Shortland, 2008; Harrison and Michailova, 2012; Kapiszewski, 2017; Metcalfe, 2007; Ridgway and Robson, 2017; Rodriguez and Scurry, 2014; Scurry et al., 2013) has shifted the focus towards the role of structures and arrangements in host countries, exploring the tensions unfolding amid the increasing presence of women expatriates in neo-patriarchal regions, such as the Middle East. For instance, in their study of expatriates in Qatar, Rodriguez and Scurry (2014) identified that expatriates experienced career capital stagnation and hurdles associated with formal and informal institutions (e.g. customs, traditions, codes of conduct, rules, regulations and laws). This resulted in organizations not investing in their training and development, which in turn affected their ability to progress in their careers.

A useful lens to analyse the impact of these structures and arrangements on women expatriates is the notion of 'gendered institutions' (Acker, 1990, 1992). This lens supports the view that organizations operate as sites for the reproduction of gendered patterns of difference and domination 
through decisions and procedures, images, symbols and ideologies, interactions and individual dynamics of gender performance (Acker, 1992). Gender is integral to many societal processes and the notion of gendered institutions alludes to the natural progression in the way working life is structured to provide continuity to dynamics in the social world. In the Middle East, the social and working lives of women are structurally organized around marriage and motherhood as mechanisms to regulate gender roles for both men and women. For instance, Rashad et al. (2005: 2) note that marriage bestows 'prestige, recognition, and societal approval' to women and leave single women without a defined space in society. In addition, the centrality of women's reproductive function, alongside religious norms, sees the regulation of women's public interactions through the use of segregated spaces (Le Renard, 2008; Moghadam, 2003). In organizations, gendering is then seen in the way power is distributed, legitimacy is awarded and individuals are controlled, segregated and excluded.

The lack of autonomy of the gender system is reinforced by hegemonic masculinity, where men are dominant actors in social and economic life, with employers openly favouring male job seekers (World Bank, 2007). As a result, women's disadvantage is perpetuated by institutions and organizations through what could be termed gendered structural inequality, whereby formal and informal regimes that regulate gender roles are embedded in the organization of work as well as in relational dynamics. In the case of women expatriates in the Middle East, this gendered structural inequality has the added complexity that as expatriates, they are a privileged group in the labour market, yet as women they remain socially disadvantaged. For instance, political regulation, such as labour nationalization policies ${ }^{1}$ are said to disproportionately affect women because they reproduce gendered norms through a wider regulatory framework that includes migration, citizenship and employment regulations (Forstenlechner, 2009; Harry, 2007; Metcalfe and Rees, 2010). Furthermore, where there are formal institutions and policies to encourage gender equality, informal traditions and cultural norms have limited this equality from materializing (Alhejji et al., 2016). In this respect, a more nuanced approach is needed to explore the features of this complexity and their role in shaping the experiences of women expatriates.

Given the role of these regulations in reproducing the gendered socio-cultural order, it could be argued that institutional and organizational arrangements, such as laws and policies that affect employment protection and rights in the Middle East, are gendered. These regulations promote lack of employment flexibility, less favourable wages, discrimination in employment selection and limited career progression (Al-Waqfi and Al-Faki, 2015), so it is important to bring to the fore the experiences of women expatriates as part of a cycle of simultaneous privilege and disadvantage. This helps us to interrogate the narratives of success associated with global mobile professionals and gain a better understanding of the cycles of disadvantage that affect particular groups of workers, such as women expatriates.

\section{Focusing on the simultaneity of privilege and disadvantage to understand experiences of women expatriates in the Middle East}

As previously noted, most discussions about expatriate workers have presented expatriates as inherently privileged by virtue of their mobility, with assumptions about them being highly skilled and consequently very desirable in global labour markets. Nevertheless, the conceptualization of expatriation based solely on attributions of privilege obscures discrete sources of discrimination (Crenshaw, 1991). For instance, Haak-Saheem and Brewster (2017) have drawn attention to 'hidden' expatriates described as 'generally young, a mix of men and women, coming mainly from developing countries and working in lower-management, manual and menial roles across industries' (p. 435). While these groups form a large majority of the expatriate workforce in the GCC, 
their heterogeneity has led to the articulation of informal hierarchies rooted on ethno-class distinctions between the migrant communities they belong to. These differences are sustained by economic and social factors used to differentiate 'elite' privileged Western professional expatriates from unskilled migrant workers (Jamal, 2015; Strabac et al., 2018; Valenta and Jakobsen, 2016).

It is important to acknowledge that the notion of expatriates as an 'elite' is one dimension of complex dynamics that bring together advantage and disadvantage resulting from the combined influence of structural, disciplinary, hegemonic and interpersonal domains (Acker, 1990, 2012; Collins, 2015; Holvino, 2010; Rodriguez et al., 2016). For instance, while the positioning of 'elite' Western expatriates might be privileged in relation to unskilled migrant workers, it is also disadvantageous in relation to national citizens as a result of nationalization agendas. The latter is materialized through higher salaries and promotion opportunities being offered to national citizens, even if they are less qualified or experienced than their expatriate counterparts (Kemp and Rickett, 2017; Syed and Metcalfe, 2017).

The study of privilege has been isolated from simultaneous considerations of disadvantage. Most studies have been framed primarily in relation to the way particular groups enjoy a privileged status based on assumptions about these groups being 'the societal norm' that sets the benchmark for other groups (Crenshaw, 1989, 1991; Wildman and Davis, 1997). Inspired by intersectionality discussions, recent works (e.g. Carrim and Nkomo, 2016; Croteau et al., 2002; Holvino, 2010; Rodriguez et al., 2016; Ruiz Castro and Holvino, 2016) have focused on the simultaneous experience of privilege and disadvantage in work and organizations, arguing that they cannot be seen as separate or fixed and should be explored as part of a dialectic process of invocation whereby subject positioning is negotiated through shifts between the two. Privilege is then a 'dynamic, relational and unstable phenomenon' (Mavin and Grandy, 2016: 380) that is intrinsically linked to disadvantage and centred on power relations that are fluid, interactive and uneven.

In this article, we engage with the idea that we need to move beyond a fixed understanding of privilege to one that considers the importance of debunking the binary position used to discuss it. For example, it is important to interrogate how categories of difference are brought to the fore in particular settings, structures and interactions, to explain how power shifts shape the experiences of individuals and groups in ways that reveal the simultaneity of privilege and disadvantage. Thus, the complexity of intersectionality is useful to challenge this presentation of privilege that seems to support the hegemony of the 'white, middle class perspective'. Conversely, the complexity of contemporary work settings calls for a more comprehensive exploration of privilege and disadvantage, in particular if we consider how socio-cultural and institutional structures and arrangements play a role in these dynamics.

In this context, the disadvantage experienced by women expatriates comes by the hand of intersectional dynamics where gender alongside, for instance, racio-ethnicity, nationality, class and citizenship, are used as mechanisms to perpetuate their disadvantage (Bose, 2012; Rottmann and Ferree, 2008; Yuval-Davis, 2007). Thus, dynamics of privilege and disadvantage can be seen as the result of complex intersections between these categories of social difference, sustained by hierarchies that emerge from exclusion, racialization, and unequal access to social and political resources based on how individuals are positioned, as well as how they position themselves within institutional and organizational arrangements (Acker, 1990, 2012; Anthias, 2013).

\section{Methodology}

In this article we are interested in showing how the life and work experiences of women expatriates are shaped by simultaneous instances of privilege and disadvantage. Participants in this study were located in either Kuwait, Qatar or the United Arab Emirates. All had previous international 
Table I. Institutional, legal and social factors influencing women in Kuwait, Qatar and UAE.

\begin{tabular}{llllll}
\hline Country & $\begin{array}{l}\text { Family } \\
\text { code (1) }\end{array}$ & $\begin{array}{l}\text { Gender Equality } \\
\text { Index (2) }\end{array}$ & $\begin{array}{l}\text { Female labour force } \\
\text { participation (3) }\end{array}$ & $\begin{array}{l}\text { Equal } \\
\text { remuneration (4) }\end{array}$ & $\begin{array}{l}\text { Discrimination in } \\
\text { employment (5) }\end{array}$ \\
\hline Kuwait & 0.8 & 0.335 & $57.0 \%$ & Not ratified & Ratified; in force \\
Qatar & 0.8 & 0.542 & $99.3 \%$ & Not ratified & Ratified; in force \\
UAE & 0 & 0.232 & $47.5 \%$ & Ratified; in force & Ratified; in force \\
\hline
\end{tabular}

(I) Data relating to family code reflects social practices such as early marriage, guardianship of children and restricted civil liberties; a score of 0 indicated no discrimination and a score closer to I suggests embedded discrimination (OECD, $2017 \mathrm{a}, 2017 \mathrm{~b})$.

(2) The Gender Equality Index indicates the inequality between men and women in the labour market; a score of 0 would suggest equality (United Nations Development Programme, 20I6).

(3) Female labour force participation shows the participation in the labour force as a percentage of the female working age population (International Labour Organization, 2018).

(4) and(5) Each country's approach to equal remuneration and discrimination in employment were obtained from the International Labour Organization (International Labour Organization, 2017).

experience and some had experience of working within the GCC region as well as other Middle Eastern countries, namely Egypt, Israel and Yemen. Table 1 provides details of some of the formal institutional, legal and social factors influencing women in the countries where the sample of participants was located.

Data used in this article are part of two larger qualitative studies conducted separately by both authors about the life and work experiences of expatriates in the GCC. For the purpose of this article, we combined data sets of women expatriates in our samples, which was possible due to the similarity of our studies in terms of the thematic focus and methodological approach. Both the authors used a combination of purposive and snowball sampling. A breakdown of the demographic details of participants reported in this article is provided in Table 2. All participants have been allocated pseudonyms to protect their anonymity. In the reporting of the findings, our convention for citing interview data is: Interviewee pseudonym, Place of residence.

Data were gathered through semi-structured interviews conducted with 34 women expatriates. Interviews lasted on average 1.5 hours and in all cases were conducted in English (either face-toface or using a voice-over-Internet protocol), digitally recorded and transcribed verbatim. We asked participants about their motives for expatriating to a GCC country and the trajectory of their professional and personal lives in the host country. We were particularly interested in their accounts about their interactions with others (immigration officials, other expatriates, locals, etc.) and how these interactions shaped their experiences in the context. Data coding and analysis were structured using QSR NVivo11. Our analysis of the data paid attention to how the women positioned themselves narratively; as Cole (2009) has noted, 'narrative can illuminate often hidden complexities while seeking to avoid simplistic generalizations and essentialisms' (p. 563).

We drew insights from intersectionality to analyse the data. Our analytical strategy followed the work of Strauss and Corbin (1998) and employed a template analysis process (King and Brooks, 2017). Following similar efforts (e.g. Carrim and Nkomo, 2016; Gioia et al., 2012; Silva et al., 2014) in data reduction of qualitative findings, we conducted the coding in three stages. The first stage involved open coding, where we read all interview transcripts independently and used a combination of a priori codes that drew on existing literature, such as 'expatriates as experts' (see Rodriguez and Scurry, 2014) and 'lack of support for work/life balance' (see Harris, 2004; Mäkelä et al., 2011), and codes that emerged from participants' narratives. The second stage involved axial coding, conducted via a collaborative interpretive reading of transcripts where we drew on Acker's $(1988,1990,1992)$ notion of gendered institutions to interpret the first codes and assign the 
Table 2. Participants.

\begin{tabular}{|c|c|c|c|c|c|}
\hline Pseudonym & Age range & Country of origin & Host country & Education level & Condition of entry \\
\hline Andie & $4 I-50$ & UK & UAE & Graduate & Assigned expatriate \\
\hline Angela & $21-30$ & UK & UAE & Graduate & Assigned expatriate \\
\hline Ana & $21-30$ & Russia & UAE & Graduate & Self-initiated expatriate \\
\hline Amal & $31-40$ & UK & UAE & Graduate & Self-initiated expatriate \\
\hline Cara & $31-40$ & UK & Qatar & Postgraduate & Self-initiated expatriate \\
\hline Carla & $31-40$ & Peru & Qatar & Graduate & Self-initiated expatriate \\
\hline Cristina & $31-40$ & Romania & UAE & Postgraduate & Self-initiated expatriate \\
\hline Daisy & $31-40$ & UK & UAE & Postgraduate & Self-initiated expatriate \\
\hline Diana & $31-40$ & UK & UAE & Graduate & Assigned expatriate \\
\hline Elena & $31-40$ & Romania & Qatar & Postgraduate & Assigned expatriate \\
\hline Elisa & $21-30$ & UK & UAE & Graduate & Assigned expatriate \\
\hline Ellie & $4 I-50$ & UK & UAE & Postgraduate & Self-initiated expatriate \\
\hline Fay & $31-40$ & UK & UAE & Graduate & Assigned expatriate \\
\hline Irma & $4 I-50$ & Philippines & Qatar & Graduate & Self-initiated expatriate \\
\hline Isla & $31-40$ & UK & UAE & Postgraduate & Self-initiated expatriate \\
\hline Kami & $31-40$ & India & Qatar & Graduate & Self-initiated expatriate \\
\hline Karen & $4 I-50$ & USA & UAE & Postgraduate & Self-initiated expatriate \\
\hline Kelly & $4 I-50$ & USA & UAE & Graduate & Self-initiated expatriate \\
\hline Leona & $31-40$ & USA & UAE & Graduate & Self-initiated expatriate \\
\hline Lorraine & $31-40$ & UK & UAE & Graduate & Assigned expatriate \\
\hline Maddie & $31-40$ & UK & Qatar & Graduate & Self-initiated expatriate \\
\hline Mina & $31-40$ & UK & UAE & Graduate & Self-initiated expatriate \\
\hline Martha & $4 I-50$ & USA & UAE & Postgraduate & Self-initiated expatriate \\
\hline Noreen & $31-40$ & UK & UAE & Postgraduate & Self-initiated expatriate \\
\hline Nuria & $51-60$ & UK & Qatar & Graduate & Self-initiated expatriate \\
\hline Ola & $31-40$ & Philippines & Qatar & Graduate & Self-initiated expatriate \\
\hline Rita & $4 I-50$ & US & UAE & Graduate & Self-initiated expatriate \\
\hline Sadeen & $21-30$ & Jordan & Kuwait & Postgraduate & Self-initiated expatriate \\
\hline Stacey & $21-30$ & UK & UAE & Graduate & Self-initiated expatriate \\
\hline Susan & $21-30$ & UK & UAE & Graduate & Assigned expatriate \\
\hline Tania & $31-40$ & UK & UAE & Graduate & Assigned expatriate \\
\hline Terri & $21-30$ & UK & UAE & Graduate & Self-initiated expatriate \\
\hline Tia & $31-40$ & Philippines & Qatar & Graduate & Self-initiated expatriate \\
\hline Viola & $5 I-60$ & UK & UAE & Postgraduate & Assigned expatriate \\
\hline
\end{tabular}

theoretical categories that led us to an agreed coding template. The third stage involved aggregating theoretical categories into the thematic dimensions of privilege and disadvantage, which reflected tensions we identified emerging from the data. These aggregate theoretical categories highlight how gendering operates in this context, whereby 'advantage and disadvantage, exploitation and control, action and emotion, meaning and identity, are patterned through and in terms of a distinction between male and female, masculine and feminine' (Acker, 1990: 146). Table 3 provides an example of our data structure.

In the next section, we discuss the empirical findings using three analytical domains where we unpack dynamics and processes of privilege and disadvantage: (1) the wider institutional context, (2) organizational processes and (3) social and relational experiences. 
Table 3. Data structure.

\begin{tabular}{|c|c|c|}
\hline First-order codes & $\begin{array}{l}\text { Second-order theoretical } \\
\text { categories }\end{array}$ & $\begin{array}{l}\text { Aggregate thematic } \\
\text { dimensions }\end{array}$ \\
\hline $\begin{array}{l}\text { Expats brought into the country as experts } \\
\text { Expats respected as professionals } \\
\text { Expats have a better work ethic than locals } \\
\text { Country needs expats for their skills }\end{array}$ & $\begin{array}{l}\text { Elite professional status of } \\
\text { expatriates as workers - symbolic } \\
\text { structures create abstract } \\
\text { hierarchical understandings of } \\
\text { worker based on levels of skill } \\
\text { (Acker, 1990: 149) }\end{array}$ & \multirow[t]{2}{*}{ Privilege } \\
\hline $\begin{array}{l}\text { Giving the impression of leading an easy life } \\
\text { Able to afford standard of living not available } \\
\text { back home } \\
\text { Able to pay for domestic help (e.g. a cleaner) }\end{array}$ & $\begin{array}{l}\text { Elite social status - processes that } \\
\text { are 'related to and powerfully } \\
\text { support the reproduction of the } \\
\text { class structure' (Acker, 1990: I46) }\end{array}$ & \\
\hline $\begin{array}{l}\text { Lack of support to balance work and life } \\
\text { Women assigned roles that are not strategic } \\
\text { Lack of autonomy at work } \\
\text { Subordination when dealing with male } \\
\text { superiors }\end{array}$ & \multirow[t]{2}{*}{$\begin{array}{l}\text { Gendered structure of work - } \\
\text { 'division of labour, }[\ldots] \text { allowed } \\
\text { behaviors }[\ldots] \text { construction of } \\
\text { divisions along the lines of gender' } \\
\text { (Acker, 1990: 146) }\end{array}$} & \multirow[t]{3}{*}{ Disadvantage } \\
\hline $\begin{array}{l}\text { As a woman, expected to do as told } \\
\text { Exclusion from meetings for being a woman/ } \\
\text { clients prefer dealing with men }\end{array}$ & & \\
\hline $\begin{array}{l}\text { Need to be cautious about how to dress and } \\
\text { act } \\
\text { As a woman, not expected to express } \\
\text { opinions } \\
\text { Needing authorization from husband to } \\
\text { work }\end{array}$ & $\begin{array}{l}\text { Gendered social structures }- \\
\text { 'forms of language, ideology, }[\ldots] \\
\text { dress }[\ldots] \text { patterns that enact } \\
\text { dominance and submission' (Acker, } \\
\text { I990: I46-I47) }\end{array}$ & \\
\hline
\end{tabular}

\section{Empirical findings: navigating privilege and disadvantage in life and work in the Middle East}

\section{The wider institutional context of the Middle East}

The simultaneity of privilege and disadvantage emerged as a defining feature of the experiences of women expatriates in the GCC. The women explained their arrival to the GCC as part of a grand narrative of freedom, mobility and job market desirability, where they used metaphors such as 'new challenge', 'different world' and 'adventure' to describe their initial impressions and expectations. This echoes what has been reported in the literature (Doherty et al., 2011; Scurry et al., 2013) about the idealistic way in which expatriates explain their motives and expectations about host settings. Nevertheless, the women also showed awareness of structural forms of inequality enforced by regimes in these countries, which position them in subordinate positions in relation to men:

[As an educated expatriate] I had that confidence then that I would get a job and it would be okay. But it was interesting to move from being a ... moving out here and being a housewife ... I felt really embarrassed and a bit like, oh you know, I've worked really hard at my education and now it says I'm a housewife on my passport. So I suppose it was kind of ... yeah, that was a bit difficult. (Daisy, Abu Dhabi)

Migration regulation, as an institutionalized strategy of power, plays a role in the way privilege is both awarded and undermined for expatriates. On one hand, expatriates benefit from the significant 
shortage of skilled labour in the GCC and are widely sought after in a region that values their skills and experience. On the other hand, migration regulation is very rigid and categorizations are applied to different groups (Kapiszewski, 2004). For instance, while single women are unable to enter to live in a GCC country without a job, married women entering a GCC country without a job can be sponsored by their husbands and receive a visa stamped as 'housewife'. Some of the women expressed that this located them in a particular social position that did not recognize their individual accomplishments. Daisy's case shows how assumptions and expectations about gender roles are used to frame the citizenship status of women; migration regulations form part of wider mechanisms that seek to frame women's position as part of a specific gender regime of subordination in society, ultimately shaping the nature of their subsequent interactions through the institutional boundaries they create.

The implication of a woman's status as a housewife is the dependency on the husband as the main breadwinner, which reflects the traditional societal structure in the Middle East, where men are recognized as sole breadwinners of families (Metcalfe, 2007). In that respect, despite all the women expatriates in our sample being working women, those who entered the countries with a spouse who had a job before they secured one, had to accept entering these countries as 'housewives' in order to be able to accompany their spouses. Importantly, as we will discuss later, the transition from 'housewife' to 'worker' became difficult as a result of this status.

Tensions in relation to how women themselves narratively navigated privilege and disadvantage were raised by the women in their accounts. While in cases such as Daisy's, the status of housewife was perceived to undermine individual accomplishments, other women acknowledged that one of the implications of being classed as a housewife was the creation of the imaginary of an easy life. Expatriate housewives in the Middle East lead lives that show features of middle-classness reminiscent of the 'Stepford wives' metaphor and its fetichization of housework (Silver, 2002). The following quote illustrates a narrative connection made between being a housewife and having a comfortable financial situation:

[I] really enjoyed that element of a being a bit of a housewife, of being able to support [husband] get settled, make sure that we have a house, make sure we have all the ... everything set up so he can just focus on his job, and I can do that. And to be that supportive role I enjoyed, even though it had a lot of stigma for me. (Kelly, Abu Dhabi)

There is a class undertone to the idea of 'being a bit of a housewife', which has been discussed in reference to the 'expat bubble' (Fechter, 2007, 2016), which alludes to the creation of artificial narratives that re-produce imagined lives of privilege that expatriates may be afforded in host countries in ways that do not, or would unlikely, resemble their lives in their home countries. In this sense, we could see Kelly's comment as an example of the (re)articulation of privilege in a way that negates the disadvantage that the label of 'housewife' otherwise creates as a result of the stigma she still recognizes.

Another instance where the privileged status conferred to expatriates was undermined by the socio-institutional order was through distinctions that defined the social standing of women based on their marital status. The perceived social credibility of married women was highlighted by single women in our sample, who noted that, in contrast, they experienced many challenges in these societies:

For a woman especially, you have to be careful and respectful. Back home you can walk, take public transport, you can wear what you like, and do whatever you want to. You have to follow the rules here. You have to be careful when you speak, and act. It's a good place for a family, but for a single person, it's hard. 
They are very family oriented here, back home it's more independent. Just the general lifestyle is very different. (Krithika, Doha)

Krithika's experience echoes what has been reported about the lives of single women in the Middle East, where women remain spatially segregated despite generational and social changes that see many pursuing higher education (Le Renard, 2008). Given the centrality of marriage and motherhood in the organization of social life, single women do not have a legitimate space and this is regulated through institutionalized mechanisms, such as the presence of chaperones in interactions in the public domain.

Most women expatriates in our sample reported being unfamiliar with these dynamics and their salience in the social structures in the Middle East, which they perceived did not allow them to exercise their full personhood. Organizationally, this translated into a lack of work opportunities for single women with some countries either forbidding, and others not easily allowing work permits for single women expatriates or even married women expatriates not accompanied by a spouse (Naithani and Jha, 2009).

However, while married women enjoyed the privilege of social approval in ways that single women did not, gender appeared to always supersede the privileges awarded by marriage. Some married women in our sample noted that the simultaneous career pursuit of both themselves and their partners involved strategic decision-making in order to navigate the family and mobility demands of dual-career couples (Patton and Doherty, 2017). This resulted in challenges for the women in cases where they travelled first to the Middle East; for example, one participant noted that she moved first with her small children to secure accommodation, register the children at a school and undertake other tasks associated with setting up home in Qatar, while her spouse dealt with the sale of the family home and the logistics of household relocation. This proved problematic for her given the lack of support from her employer:

I'd worked in the UK business for such a long time and having had two children there, appreciated, and was to a certain extent complacent about the amount of flexibility I had. I was able to work part time; I was told that I couldn't when I came to the Middle East that there was no part time working. I was told, because I was working on this project that I was $100 \%$ billable and that any time that I needed to take out, you know, they'd have to get approval for from the client. That was a real shock to the system, because obviously having arrived a day earlier with two small children under the age of five, I was facing a very difficult situation and, to a certain extent, difficult decision, you know, do I carry on doing this and make it work or do we just say no, it's not for us and leave. And that was ... they were serious decisions that I had to make very quickly, and face the kind of conversation with colleagues that were, you know, if you're going to make it work this is what you have to get in place, this is what you're going to have to do; this is additional costs that you're going to have to incur - none of that was foreseen before we arrived. (Cara, Doha)

The lack of organizational support for the needs of diverse female workers shows organizational unfamiliarity with, and disregard for, their needs. This could be the result of the small number of women in the workforce in the country; statistics produced by Qatar's Ministry of Development Planning and Statistics (State of Qatar, 2018) indicate that 14\% of the workforce in the country are women, of which $87 \%$ are expatriates. In that respect, the privileged status Cara derived from being an expatriate who secured a very lucrative job was undermined by the organizational precariousness related to the lack of support to help her to navigate the initial demands of work and life as a mother of young children.

As policies of localization stress that organizations invest in the local workforce, there is limited support for expatriates (Rodriguez and Scurry, 2014); conversely, given the small number of local 
women in the private sector, there are limited developmental opportunities for this group in general terms so the needs of women may not be at the top of organizational agendas. The underpinning centrality of gender in the articulation of institutional dynamics results in logics that prioritize gendered notions of family and kinship (Acker, 1990). For instance, the dominant understandings of family in the Middle East, which are said to be reductionist and functionalist and reinforce status expectations built around a central male figure as head of household and face of the family in the public domain (Moghadam, 2004).

\section{Organizational processes in the Middle East}

Access to the world of work also exemplified the tensions linked to the simultaneity of privilege and disadvantage experienced by women expatriates. For most of the women, the route to employment appeared more complex than what they had encountered in their home countries mainly due to difficulties in establishing networks (wasta). The complexity of wasta is linked to how the strength of networks emanates from connections sustained by family, kinship and obligation and imply 'the exercise of power, influence and information sharing through social and political business networks' (Hutchings and Weir, 2006: 143). In practice, this translates into employment opportunities materializing through social networking, without any accompanying formal process of recruitment and selection, which affected women in our sample, particularly self-initiated expatriates, as they did not have established connections:

I think job hunting was really difficult and I think everybody tells you it's all about who you know. And the annoying thing is when you arrive you don't know anybody. So there's a lot of that and it's really true, when you're going through, you know, the websites and stuff you feel like your applications are going into black holes. (Daisy, Abu Dhabi)

This disadvantage was enhanced by the limited instances of socialization available to the women due to gender segregation. Given that exchanges are only allowed in women-only spaces, women expatriates do not gain access to wider networks linked to employment opportunities because these are mainly dominated by men. As a result, women expatriates are mainly able to socialize with other women who themselves often do not work, which limits their agency and the support they need to develop a strategy of social capital accumulation to advance their careers (Kumra and Vinnicombe, 2010).

Organizationally, there is an important tension that unsettles the privilege of women expatriates. Fechter (2016) notes that the very concept of the 'expat expert' is the overriding narrative that accompanies the presence of expatriates and is used to justify their position and explain their privilege in host settings. However, despite women expatriates enjoying a privileged status, which includes the freedom to access particular jobs that local women may be unlikely to enter, competitive merit is not what allows these women to secure a job, given the more complex dynamics at play. In particular, the women are subordinated to the dominant groups (expatriate men and local men) in the form of regulations established at the institutional level and implemented through organizational practices. For example, the dependency on husbands (or male sponsors) in order to be able to take up any form of employment, as well as a generalized dynamic that subordinates women's voices in interactions in public spaces:

You know, people addressing [my husband] instead of me, but it's me with the issue. You know, it's ... and even I suppose getting a job. Because [my husband] had to say that he consented to me having a job, and having a driver's license, and things like that. I think it's quite an eye opener having your husband have to sign [a no objections certificate] to say that you're allowed to work and drive. (Kelly, Abu Dhabi) 
The guardianship system requiring that men (e.g. fathers, husbands or brothers) sign a written declaration of consent to indicate that they do not object to women undertaking employment before women are able to look for employment, is perhaps one of the strongest ways in which women are disadvantaged in the labour market. This restricts their personal freedom, granting formal powers to the men in their lives to legitimize their actions and veto their activities. Furthermore, the complexity of this form of patrilineality in social relations (see Joseph and Slyomovics, 2011) is reconfigured in relation to women expatriates because they normally do not have extended family with them. Some women expatriates noted that their husbands found this procedure inconsequential and recognized it as a contextual hurdle to get out of the way. Nevertheless, its presence speaks of institutionalized mechanisms that disadvantage women by limiting their personhood and stripping them of individual agency in the public domain, which challenged the experiences of women expatriates in the labour market and their ability to make independent decisions with regard to pursuing work and developing their careers.

\section{Social and relational experiences in the Middle East}

Women's experiences at work and in the social world were diverse and characterized by the constant negotiation of contradictions between their status as professional experts and the disadvantage associated with gendered structures (Acker, 1990). Women's narratives highlighted tensions of inhabiting contradictory spaces in the social world: on one hand, due to skills shortage, the Middle East has a strong reliance on expatriate labour; on the other hand, being women was at the centre of their struggles with gendered norms and structures. Mechanisms of disadvantage appeared to be framed within formalized interactions, which may explain why some women noted that despite the lack of opportunities and progression, they still felt treated with respect and deference at work by their male peers.

Acker (2012) has noted that gendered substructures help to reproduce societal beliefs about gender, equality and inequality in work settings. In this respect, the respectful treatment of women expatriates is not inconsistent with the ways in which women are kept at a distance by men in the Middle East. Some participants note that their presence seemed to be tolerated rather than valued; for example while being invited to meetings, their views and expertise were completely ignored. This echoes what Gherardi (1994) has noted about the way we do gender at work, which reinforces particular gendered features in organizations that reproduce societal norms and increase inequalities between men and women. Ultimately, the lack of engagement with women expatriates obscures claims of disadvantage as the formalized nature of interactions would counter the argument that women are mistreated by men at work. This tension is highlighted in the following comment:

Men tend to look at you as a secondary citizen. They feel they are stronger, and you are not able to do your job as well as them, your abilities are only this much. They also think that all the top positions should be for males and they can progress better. It's very male dominated here. And I think because of the mentality, that becomes a barrier for the woman to advance in her career. We are still treated with a level of respect. I have been treated well though. (Amy, Doha)

There is increasing acknowledgement of the reconfiguration of patriarchal regimes insofar as they no longer rely on the dichotomization of private and public spaces, and their impact on the experiences of women. For instance, in this context, the power of local men as the dominant group is central to unsettling the status of women expatriates in work settings. It has been noted (see Moghadam, 2003: 5) that gender relations draw heavily on religion and cultural norms, governing 
women's work, positioning them as illegitimate within the work domain and reinforcing patriarchal views that they should not be part of the labour force. As a result, the presence of women expatriates is contentious and the women recognized that they had to adopt a cautious approach in their interactions with local men:

You always have to be aware of what you say, to make sure you don't say anything disrespectful. I always am extremely cautious 'cause you don't want them to take anything the wrong way. (Emily, Dubai)

The regulation of social interactions is further legitimized by the role of the state in the politics of male-female relations (Joseph and Slyomovics, 2011) enforced through strict gendered social norms. Expectations of appropriate gendered behaviour in the Middle East are related to a code of modesty as a pillar of respectable femininity and upon which rests the dignity and reputation of women (Metcalfe, 2007; Stalker and Mavin, 2011). It is important to note that while the underlying principle that sustains the practice of chaperoning women in public spaces is related to preserving their virtue and respectability, it is also a way of reinforcing male dominance in the public domain. One participant recounted the following about interactions with local men outside of the workplace:

Sometimes you encounter men who show you respect, and some harass you. Some are rude and perverted. Few years ago, I would just be standing on the street, and they would throw their numbers at me. (Janice, Doha)

Janice then noted that these encounters had left her feeling humiliated, insulted and undermined but unable to understand what she had done to deserve this treatment. As we have noted, the spatial, institutional and discursive segregation of women is an organizing principle of social life in the Middle East (Le and Renard, 2008). As such, women who would 'just be standing on the street' by themselves could be seen to be countervailing social norms and would not be perceived as respectable. Harassment is then both a form of social punishment as much as it is a mechanism of regulation of social hierarchies between men and women, looking to reaffirm the strong gender roles in Islamic culture (Metcalfe, 2006).

In sum, there is a symbiotic interaction between organizational rules and regulations and sociocultural norms and dynamics, resulting in the articulation and reproduction of instances of privilege and disadvantage that shape the experiences of women expatriates in the Middle East. In this context, formal and informal institutions simultaneously undermine women expatriates' personhood and the possibilities to make choices about their life, work and careers.

\section{Conclusion, contributions and directions for future research}

This article set out to explore how privilege and disadvantage shape the work and life experiences of women expatriates in the Middle East, specifically in GCC countries. The experiences of the women expatriates discussed in this article help to open up a wider discussion about the importance of problematizing privilege and its understanding. Traditionally, privilege has been opposed to disadvantage instead of exploring it as a continuous process of negotiation where both coexist as part of systemic processes that institutionally, organizationally and relationally affect particular groups. Furthermore, the positioning of this discussion in the context of the Middle East highlights ways in which social and work domains intersect to create dynamics that distinctly position women expatriates within complex tensions that they constantly negotiate. 
An important consideration is that the prevalent premise in discussions about the privileged is that they have tended to benefit from the exclusion of others (Johnson, 2006; Reiter, 2013). In this respect, there is dichotomization of individuals and groups involved in these dynamics, which overlooks the simultaneous negotiation of privilege and disadvantage. In this article, we have shown how the experiences of women expatriates are shaped by shifts in power in social and work domains, which constantly re-position them within environments in the Middle East. In line with intersectional understandings of simultaneity (see Holvino, 2010), we conclude that privilege and disadvantage are inseparable to the way the experiences of women expatriates unfold in the Middle East. On one hand, women expatriates are privileged because as expatriate professionals, they are part of a group of workers that enjoys an elite status both globally and in the context of the Middle East. On the other hand, as women, they experience disadvantage resulting from the strength of the patriarchal regimes in the context. In this respect, there is important insight to be gained from the way the institutional setting articulates this inseparability in order to regulate and maintain the gender social order in organizational and social life (Acker, 1990).

In contextualizing the life and work experiences of women expatriates in relation to dynamics of privilege and disadvantage, the article shows that the experiences of this group should not be generalized to a homogeneous understanding of what it means to be skilled and mobile in global labour markets. Throughout the article, we allude to the need for nuance in the exploration of the experiences of women expatriates in order to challenge dominant gender-neutral narratives about expatriates, which sustain ideas about expatriates as an elite group while obscuring the disadvantage experienced by women. In this respect, our findings support Acker's (1990) idea that in looking to present work as gender-neutral, the gendering that underpins organizational logics is both obscured and enhanced. We have contributed to this nuanced exploration by moving away from a positioning that focuses on success and/or failure of expatriate experiences, instead of looking to gain insight into the dynamics that shape their experiences amid conflicting positions.

Discussions in this article highlight that the status of women expatriates as a privileged elite needs to be further interrogated, adopting an integrated framework that looks at how institutions, organizations and relationships impact career choices and the experiences of international work more generally, especially in the Middle East. While women's labour mobility can be seen as an indicator of ways in which they enter spaces of privilege and increase their global capital, and economic and social mobility, these also come attached to reconfigured forms of disadvantage. These forms play a role in shaping their experiences in ways that differ from local women, local men and expatriate men. In this article, the neo-patriarchal dynamics prevalent in the Middle East helped us to illustrate this.

However, it is worth noting that while there are common features in GCC countries, such as Islam being the predominant religion, Arabic the native language and a hierarchical culture (Al-Omari, 2008; Kabasakal and Bodur, 2002; Williams, 2010), which play a fundamental role in shaping the life and work experiences of women expatriates, the economic, political and socio-cultural features of each of the countries should not be taken as generalizable. In addition, we must recognize that similar dynamics have been found in other regions, for instance, machismo and patronage in Latin America (Gomez and Rodriguez, 2006). This suggests there are important avenues for advancement of discussions by focusing more comprehensively on the exploration of institutional varieties as well as localized reformulations of gender(ed) regimes, also looking to develop comparative work across regions of the Global South. This would help to further our understanding of how cultural, institutional and organizational factors intersect to shape the experiences of women expatriates and help to develop strategies to support them in host settings. 


\section{Acknowledgements}

The authors would like to thank the editors of the special issue and the anonymous reviewers for their careful reading and engagement with the different versions of this article. The corresponding author would also like to thank Sarah Bailouni for her research assistance in the collection and transcription of the empirical data of one of the data sets reported in this article.

\section{Note}

1. Nationalization policies, also known as localization policies, look to promote the employment participation of locals by investing and supporting them to improve their skills and enhance their employability to address the skills mismatch between local graduates and the needs of the private sector (Forstenlechner, 2010; Forstenlechner and Rutledge, 2010, 2011; Rutledge et al., 2011).

\section{ORCID iDs}

Jenny K. Rodriguez (iD https://orcid.org/0000-0001-9288-6125

Maranda Ridgway (iD https://orcid.org/0000-0003-4426-6516

\section{References}

Acker, J. (1988) 'Class, Gender, and the Relations of Distribution', Signs: Journal of Women in Culture and Society 13(3): 473-97.

Acker, J. (1990) 'Hierarchies, Jobs, Bodies: A Theory of Gendered Organizations', Gender \& Society 4(2): $139-58$.

Acker, J. (1992) 'From Sex Roles to Gendered Institutions', Contemporary Sociology 21(5): 565-69.

Acker, J. (2012) 'Gendered Organizations and Intersectionality: Problems and Possibilities', Equality, Diversity and Inclusion: An International Journal 31(3): 214-24.

Adler, N. J. (1984) 'Women Do Not Want International Careers: And Other Myths about International Management', Organizational Dynamics 13(2): 66-79.

Al Ariss, A., Koall, I., Ozbilgin, M., et al. (2012) 'Careers of Skilled Migrants: Towards a Theoretical and Methodological Expansion', Journal of Management Development 31(2): 92-101.

Alhejji, H., Ng, E. S., Garavan, T., et al. (2016) 'The Impact of Formal and Informal Distance on Gender Equality Approaches: The Case of a British MNC in Saudi Arabia', Thunderbird International Business Review 60: 147-59.

Al-Omari, J. (2008) Understanding the Arab Culture. Oxford: How To Books Ltd.

Altman, Y. and Shortland, S. (2008) 'Women and International Assignments: Taking Stock - A 25-Year Review', Human Resource Development Quarterly 47(2): 199-216.

Al-Waqfi, M. A. and Al-Faki, I. A. (2015) 'Gender-Based Differences in Employment Conditions of Local and Expatriate Workers in the GCC Context: Empirical Evidence from the United Arab Emirates', International Journal of Manpower 36(3): 397-415.

Andresen, M., Biemann, T. and Pattie, M. W. (2015) 'What Makes Them Move Abroad? Reviewing and Exploring Differences between Self-Initiated and Assigned Expatriation', The International Journal of Human Resource Management 26(7): 932-47.

Anthias, F. (2013) 'Intersectional What? Social Divisions, Intersectionality and Levels of Analysis', Ethnicities 13(1): 3-19.

Beaverstock, J. V. (2002) 'Transnational Elites in Global Cities: British Expatriates in Singapore's Financial District', Geoforum 33(4): 525-38.

Bose, C. E. (2012) 'Intersectionality and Global Gender Inequality', Gender \& Society 26(1): 67-72.

Caligiuri, P. and Lazarova, M. (2002) 'A Model for the Influence of Social Interaction and Social Support on Female Expatriates' Cross-Cultural Adjustment', International Journal of Human Resource Management 13(5): 761-72.

Caligiuri, P. M. and Tung, R. L. (1999) 'Comparing the Success of Male and Female Expatriates from a US-Based Multinational Company', International Journal of Human Resource Management 10(5): $763-82$. 
Carrim, N. M. H. and Nkomo, S. M. (2016) 'Wedding Intersectionality Theory and Identity Work in Organizations: South African Indian Women Negotiating Managerial Identity', Gender, Work and Organization 23(3): 261-77.

Cole, B. A. (2009) 'Gender, Narratives and Intersectionality: Can Personal Experience Approaches to Research Contribute to "Undoing Gender"?', International Review of Education 55(5): 561-78.

Collins, P. H. (2015) 'Intersectionality's Definitional Dilemmas', Annual Review of Sociology 41: 1-20.

Crenshaw, K. (1989) 'Demarginalizing the Intersection of Race and Sex: A Black Feminist Critique of Antidiscrimination Doctrine, Feminist Theory and Antiracist Policies', The University of Chicago Legal Forum 1989(1): 139-67.

Crenshaw, K. (1991) 'Mapping the Margins: Intersectionality, Identity Politics, and Violence against Women of Color', Stanford Law Review 43(6): 1241-99.

Croteau, J. M., Talbot, D. M., Lance, T. S., et al. (2002) 'A Qualitative Study of the Interplay between Privilege and Oppression', Journal of Multicultural Counseling and Development 30: 239-58.

Doherty, N., Dickmann, M. and Mills, T. (2011) 'Exploring the Motives of Company-Backed and SelfInitiated Expatriates', The International Journal of Human Resource Management 22(3): 595-611.

Farrer, J. (2010) "New Shanghailanders" or "New Shanghainese": Western Expatriates' Narratives of Emplacement in Shanghai', Journal of Ethnic and Migration Studies 36(8): 1211-28.

Fechter, A. M. (2007) 'Living in a Bubble', in V. Amit (ed.) Going First Class? New Approaches to Privileged Travel and Movement, pp. 33-52. Oxford: Berghahn Books.

Fechter, A. M. (2016) Transnational Lives: Expatriates in Indonesia. London: Routledge.

Forstenlechner, I. (2009) 'Workforce Localization in Emerging Gulf Economies: The Need to Fine-Tune HRM', Personnel Review 39(1): 135-52.

Forstenlechner, I. (2010) 'Expats and Citizens: Managing Diverse Teams in the Middle East', Team Performance Management: An International Journal 16(5-6): 237-41.

Forstenlechner, I. and Rutledge, E. (2010) 'Unemployment in the Gulf: Time to Update the "Social Contract", Middle East Policy 17(2): 38-51.

Forstenlechner, I. and Rutledge, E. J. (2011) 'The GCC's 'Demographic Imbalance': Perceptions, Realities and Policy Options', Middle East Policy 18(4): 25-43.

Fox, J. W., Mourtada-Sabbah, N. and Al-Mutawa, M. (2006) 'The Arab Gulf Region: Traditionalism Globalized or Globalization Traditionalized?', in J. W. Fox, N. Mourtada-Sabbah and M. Al-Mutawa (eds) Globalization and the Gulf, pp. 3-59. London: Routledge.

Gherardi, S. (1994) 'The Gender We Think, the Gender We Do in Our Everyday Organizational Lives', Human Relations 47(6): 591-610.

Gioia, D. A., Corley, K. G. and Hamilton, A. L. (2012) 'Seeking Qualitative Rigor in Inductive Research: Notes on the Gioia Methodology', Organizational Research Methods 16(1): 15-31.

Gomez, C. F. and Rodriguez, J. K. (2006) 'Four Keys to Chilean Culture: Authoritarianism, Legalism, Fatalism and Compadrazgo', Asian Journal of Latin American Studies 19(3): 43-65.

Gulf Labour Markets and Migration (2017) 'GCC: Total Population and Percentage of Nationals and Foreign Nationals in GCC Countries'. Retrieved March 10, 2017, from http:/gulfmigration.eu/ gcc-total-population-percentage-nationals-foreign-nationals-gcc-countries-national-statistics-2010 -2016-numbers/?print=pdf

Haak-Saheem, W. and Brewster, C. (2017) “"Hidden” Expatriates: International Mobility in the United Arab Emirates as a Challenge to Current Understanding of Expatriation', Human Resource Management Journal 27(3): 423-39.

Harris, H. (2004) 'Global Careers: Work-Life Issues and the Adjustment of Women International Managers', Journal of Management Development 23(9): 818-32.

Harrison, E. C. and Michailova, S. (2012) 'Working in the Middle East: Western Female Expatriates' Experiences in the United Arab Emirates', The International Journal of Human Resource Management 23(4): $625-44$.

Harry, W. (2007) 'Employment Creation and Localization: The Crucial Human Resource Issues for the GCC', The International Journal of Human Resource Management 18(1): 132-46. 
Hartl, K. (2004) 'The Expatriate Career Transition and Women Managers' Experiences', Women in Management Review 19(1): 40-51.

Holvino, E. (2010) 'Intersections: The Simultaneity of Race, Gender and Class in Organization Studies', Gender, Work and Organization 17(3): 248-77.

Hutchings, K. and Michailova, S. (2017) 'Female Expatriates: Towards a More Inclusive View', in Y. McNulty and J. Selmer (eds) Research Handbook of Expatriates, pp. 241-60. Cheltenham: Edward Elgar.

Hutchings, K. and Weir, D. (2006) 'Guanxi and Wasta: A Comparison', Thunderbird International Business Review 48(1): 141-56.

Hutchings, K., Michailova, S. and Harrison, E. C. (2013) 'Neither Ghettoed Nor Cosmopolitan: A Study of Western Women's Perceptions of Gender and Cultural Stereotyping in the UAE', Management International Review 53: 291-318.

International Labour Organization (2017) 'Country Profile'. Retrieved May 8, 2018, from http://www.ilo.org /dyn/normlex/en/f?p=1000:11003:::NO:::

International Labour Organization (2018) 'Labour Force Participation Rate by Sex and Age (\%)'. Retrieved May 4, 2018, from http://www.ilo.org/ilostat/faces/ilostat-home/home?_adf.ctrl-state=2fdhcftmz_246\& afrLoop=1812636180201957\#!

Jamal, M. A. (2015) 'The "Tiering" of Citizenship and Residency and the "Hierarchization" of Migrant Communities: The United Arab Emirates in Historical Context', International Migration Review 49(3): 601-32.

Johnson, A. G. (2006) Privilege, Power, and Difference. Boston, MA: McGraw-Hill.

Joseph, S. and Slyomovics, S. (2011) 'Introduction', in S. Joseph and S. Slyomovics (eds) Women and Power in the Middle East, pp. 1-22. Philadelphia, PA: University of Pennsylvania Press.

Kabasakal, H. and Bodur, M. (2002) 'Arabic Cluster: A Bridge between East and West', Journal of World Business 37: 40-54.

Kapiszewski, A. (2004) 'Arab Labour Migration to the GCC States', in International Organization for Migration IOM and League of Arab States (eds) Arab Migration in a Globalized World, pp. 115-33. Geneva: IOM.

Kapiszewski, A. (2017) 'Arab Versus Asian Migrant Workers in the GCC Countries', in P. C. Jain and G. Z. Oommen (eds) South Asian Migration to Gulf Countries, pp. 66-90. Delhi: Routledge.

Kemp, L. J. and Rickett, B. (2017) 'The Lived Experiences of Foreign Women: Influences on Their International Working Lives', Gender, Work and Organization 25: 343-60.

King, N. and Brooks, J. M. (2017) Template Analysis. London: Sage.

Kumra, S. and Vinnicombe, S. (2010) 'Impressing for Success: A Gendered Analysis of a Key Social Capital Accumulation Strategy', Gender, Work and Organization 17(5): 521-46.

Le Renard, A. (2008) “'Only for Women”: Women, the State, and Reform in Saudi Arabia', The Middle East Journal 62(4): 610-29.

Mäkelä, L., Suutari, V. and Mayerhofer, H. (2011) 'Lives of Female Expatriates: Work-Life Balance Concerns', Gender in Management: An International Journal 26(4): 256-74.

Mavin, S. and Grandy, G. (2016) 'Women Elite Leaders Doing Respectable Business Femininity: How Privilege Is Conferred, Contested and Defended through the Body', Gender, Work and Organization 23(4): 379-96.

Metcalfe, B. D. (2006) 'Exploring Cultural Dimensions of Gender and Management in the Middle East', Thunderbird International Business Review 48(1): 93-107.

Metcalfe, B. D. (2007) 'Gender and Human Resource Management in the Middle East', The International Journal of Human Resource Management 18(1): 54-74.

Metcalfe, B. D. (2008) 'Women, Management and Globalization in the Middle East', Journal of Business Ethics 83(1): 85-100.

Metcalfe, B. D. and Rees, C. J. (2010) 'Gender, Globalization and Organization: Exploring Power, Relations and Intersections', Equality, Diversity and Inclusion: An International Journal 29(1): 5-22.

Metcalfe, B. D., Hutchings, K. and Cooper, B. (2009) 'Re-Examining Women's International Management Opportunities and Experiences: A Middle Eastern Perspective', in K. Ibeh and S. Davies (eds) Contemporary Challenges to International Business, pp. 232-50. London: Palgrave Macmillan. 
Moghadam, V. M. (2003) Modernizing Women: Gender and Social Change in the Middle East. Boulder, CO: Lynne Rienner Publishers.

Moghadam, V. M. (2004) 'Patriarchy in Transition: Women and the Changing Family in the Middle East', Journal of Comparative Family Studies 35: 137-62.

Naithani, D. and Jha, A. (2009) 'Challenges Faced by Expatriate Workers in the Gulf Cooperation Council Countries'. Retrieved August 14, 2018, from https://philpapers.org/archive/NAICFB.pdf

North, D. C. (1991) 'Institutions', Journal of Economic Perspectives 5(1): 97-112.

OECD (2017a) 'Discriminatory Family Code Indicator'. Retrieved January 5, 2018, from https://doi.org $/ 10.1787 / 7$ ce $07 \mathrm{~d} 5 \mathrm{f}$-en

OECD (2017b) 'Social Institutions and Gender Indicator'. Retrieved January 5, 2018, from https://doi.org /10.1787/7b6cfcf0-e

Patton, W. and Doherty, C. (2017) 'Career, Family, and Workforce Mobility: An Interdisciplinary Conversation', Journal of Career Development. Published online before print September 25, doi: $10.1177 / 0894845317731157$.

Rashad, H., Osman, M. and Foudi-Fahimi, F. (2005) Marriage in the Arab World. Washington, DC: Population Reference Bureau.

Reiter, B. (2013) The Dialectics of Citizenship: Exploring Privilege, Exclusion, and Racialization. East Lansing, MI: MSU Press.

Ridgway, M. and Robson, F. (2017) 'Exploring the Motivation and Willingness of Self-Initiated Expatriates, in the Civil Engineering Industry, When Considering Employment Opportunities in Qatar', Human Resource Development International 21: 24-45.

Rodriguez, J. K. and Scurry, T. (2014) 'Career Capital Development of Self-Initiated Expatriates in Qatar: Cosmopolitan Globetrotters, Experts and Outsiders', The International Journal of Human Resource Management 25(2): 190-211.

Rodriguez, J. K., Holvino, E., Fletcher, J. K., et al. (2016) 'The Theory and Praxis of Intersectionality in Work and Organizations: Where Do We Go From Here?', Gender, Work and Organization 23(3): 201-22.

Rottmann, S. B. and Ferree, M. M. (2008) 'Citizenship and Intersectionality: German Feminist Debates about Headscarf and Antidiscrimination Laws', Social Politics 15(4): 481-513.

Ruiz Castro, M. and Holvino, E. (2016) 'Applying Intersectionality in Organizations: Inequality Markers, Cultural Scripts and Advancement Practices in a Professional Service Firm', Gender, Work and Organization 23(3): 328-47.

Rutledge, E., Al Shamsi, F., Bassioni, Y., et al. (2011) 'Women, Labour Market Nationalization Policies and Human Resource Development in the Arab Gulf States', Human Resource Development International 14(2): 183-98.

Scurry, T., Rodriguez, J. K. and Bailouni, S. (2013) 'Narratives of Identity of Self-Initiated Expatriates in Qatar', Career Development International 18(1): 12-33.

Sharabi, H. (1992) Neopatriarchy: A Theory of Distorted Change in Arab Society. Oxford: Oxford University Press.

Shortland, S. (2009) 'Gender Diversity in Expatriation: Evaluating Theoretical Perspectives', Gender in Management 24(5): 365-86.

Shortland, S. (2014) 'Women Expatriates: A Research History', in K. Hutchings and S. Michailova (eds) Research Handbook on Woman in International Management, pp. 18-44. Cheltenham: Edward Elgar.

Silva, T., Cunha, M. P. E., Clegg, S. R., et al. (2014) 'Smells Like Team Spirit: Opening a Paradoxical Black Box', Human Relations 67(3): 287-310.

Silver, A. K. (2002) 'The Cyborg Mystique: “The Stepford Wives” and Second Wave Feminism', Women's Studies Quarterly 30(1-2): 60-76.

Stalker, B. and Mavin, S. (2011) 'Learning and Development Experiences of Self-Initiated Expatriate Women in the United Arab Emirates', Human Resource Development International 14(3): 273-90.

State of Qatar (2018) 'Quarterly Bulletin Labor Force Survey, First Quarter (Q1) 2018, Ministry of Development Planning and Statistics'. Retrieved September 11, 2018, from https://www.mdps.gov.qa /en/statistics/Statistical\%20Releases/Social/LaborForce/2018/Q1/LF_Q1_2018_AE.xlsx 
Stockemer, D. and Sundström, A. (2016) 'Modernization Theory: How to Measure and Operationalize It When Gauging Variation in Women's Representation?', Social Indicators Research 125(2): 695-712.

Strabac, Z., Valenta, M. and Al Awad, M. (2018) 'Temporary Labour Migration to United Arab Emirates: A Complex Story', Migration and Development 7: 352-65.

Strauss, A. and Corbin, J. (1998) Basics of Qualitative Research: Techniques and Procedures for Developing Grounded Theory. Thousand Oaks, CA: Sage.

Syed, J. and Metcalfe, B. D. (2017) 'Under Western Eyes: A Transnational and Postcolonial Perspective of Gender and HRD', Human Resource Development International 20(5): 403-14.

Tahir, R. and Ertek, G. (2018) 'Cross-Cultural Training: A Crucial Approach to Improve the Success of Expatriate Assignment in the United Arab Emirates', Middle East Journal of Management 5(1): 50-74.

UN Women (2017) 'Understanding Masculinities: Results from the International Men and Gender Equality Survey (images) - Middle East and North Africa'. Retrieved May 12, 2018, from http://www.unwomen .org/-/media/headquarters/attachments/sections/library/publications/2017/images-mena-multi-country -report-en.pdf?la=en\&vs=3602

United Nations Development Programme (2016) Human Development Report 2016. New York: United Nations Development Programme. Retrieved May 12, 2018, from http://hdr.undp.org/sites/default /files/2016 human development report.pdf

Valenta, M. and Jakobsen, J. (2016) 'Moving to the Gulf: An Empirical Analysis of the Patterns and Drivers of Migration to the GCC Countries, 1960-2013', Labor History 57(5): 627-48.

Van Bochove, M. and Engbersen, G. (2015) 'Beyond Cosmopolitanism and Expat Bubbles: Challenging Dominant Representations of Knowledge Workers and Trailing Spouses', Population, Space and Place 21(4): 295-309.

Varma, A. and Russell, L. (2016) 'Women and Expatriate Assignments: Exploring the Role of Perceived Organizational Support', Employee Relations 38(2): 200-23.

Wildman, S. M. and Davis, A. D. (1997) 'Making Systems of Privilege Visible', in R. Delgado and J. Stefancic (eds) Critical White Studies: Looking behind the Mirror, pp. 314-19. Philadelphia, PA: Temple University Press.

Williams, J. (2010) Don't They Know It's Friday, 2nd ed. Dubai, United Arab Emirates: Motivate Publishing. World Bank (2007) 'The Status \& Progress of Women in the Middle East \& North Africa', Working Paper 43648, World Bank Middle East and North Africa Social and Economic Development Group. Retrieved January 5, 2018, from http://documents.worldbank.org/curated/en/873011468299062424/The-status -and-progress-of-women-in-the-Middle-East-and-North-Africa

Yuval-Davis, N. (2007) 'Intersectionality, Citizenship and Contemporary Politics of Belonging', Critical Review of International Social and Political Philosophy 10(4): 561-74.

\section{Author biographies}

Jenny K Rodriguez is senior lecturer in Employment Studies at Alliance Manchester Business School and member of the Work \& Equalities Institute at The University of Manchester. Her research focuses on intersectional inequality in work and organisations, and the interplay between identity, work and regulation. Her current work explores the transnational experiences of skilled migrant women.

Maranda Ridgway is senior lecturer in Human Resources Management at Nottingham Business School, Nottingham Trent University. Her research areas include international human resource management, global mobility, gender and work and employee engagement. 